\title{
MOTIVATIONS AND SATISFACTION OF VOLUNTEER TOURISM FOR THE DEVELOPMENT OF A DESTINATION
}

\author{
Mauricio CARVACHE-FRANCO \\ Espíritu Santo University-Ecuador, Av. Samborondón, \\ Samborondón 092301, Ecuador, e-mail: mauricio2714@hotmail.com \\ Wilmer CARVACHE-FRANCO* \\ ESPOL Polytechnic University, Escuela Superior Politécnica del Litoral, ESPOL, \\ Faculty of Social Sciences and Humanities, Campus Gustavo Galindo Km 30.5 Vía Perimetral, \\ P.O. Box 09-01-5863, Guayaquil, Ecuador, e-mail: wcarvach@espol.edu.ec \\ Daniel CONTRERAS-MOSCOL \\ ESPOL Polytechnic University, Escuela Superior Politécnica del Litoral, ESPOL, i3lab \\ Entrepreneurship and Innovation Center, Campus Gustavo Galindo Km 30.5 Vía Perimetral, \\ P.O. Box 09-01-5863, Guayaquil, Ecuador, e-mail: dcontrer@espol.edu.ec \\ Luis ANDRADE-ALCIVAR \\ Agricultural Polytechnic Superior School of Manabí - ESPAMMFL. Department of Tourism, \\ 10 de agosto \#82 and Granada Centeno Street Calceta, Ecuador, e-mail: luisandrade7o@hotmail.com

\section{Orly CARVACHE-FRANCO} \\ Catholic University of Santiago de Guayaquil, Faculty of Business Specialties, \\ Av. Carlos Julio Arosemena Km 1.5, Guayaquil, Ecuador, e-mail: orly.carvache@cu.ucsg.edu.ec
}

Citation: Carvache-Franco, M., Carvache-Franco, W., Contreras-Moscol, D., Andrade-Alcivar, L., \& Carvache-Franco, O. (2019). MOTIVATIONS AND SATISFACTION OF VOLUNTEER TOURISM FOR THE DEVELOPMENT OF A DESTINATION. GeoJournal of Tourism and Geosites, 26(3), 714-725. https://doi.org/10.30892/gtg.26303-391

\begin{abstract}
Volunteer tourism as a contribution to society can improve various aspects of a destination such as the economy and society itself. The present empirical study analyzes the behavior of the volunteer tourist in relation to their motivations and satisfaction in their stay. The study was conducted in situ in the province of Manabí in Ecuador, a destination that was hit by an earthquake in April 2016, where volunteer tourists arrived to help with the reconstruction. The study was quantitative, a questionnaire was used, and factor analysis was used as a data reduction technique. The results show that the main motivational factor for which they arrived was "Professional and social development", followed by "Values and self-esteem". The evaluation of the overall satisfaction of this activity was high, which demonstrates the potential of this type of tourism for the destination. The vast majority of tourists would repeat and recommend a volunteer trip. The types of tourism most made during their stay were the community-based tourism, and sun and beach. Findings are useful for organizations that work with volunteers to take into account within their programs.
\end{abstract}

\footnotetext{
* Corresponding author
} 
Motivations and Satisfaction of Volunteer Tourism for the Development of a Destination

Key words: Volunteer, factors, satisfaction, motivation, earthquake, Ecuador.

\section{INTRODUCTION}

The activity of volunteering is not common in all human beings, it is praiseworthy to establish it as something innate that allows volunteers to give themselves to provide welfare to others because they feel the desire to empathize with the pain of others, but the reality differs partially from this thought, since according to studies volunteers are also motivated by experiencing new situations and / or generating job opportunities (Akintola, 2010; Barron \& Rihova, 2011; Chen \& Chen, 2011). Volunteer tourism is implementing a volunteer mission to support responsible tourism facilities (Khetagurova et al., 2018).

In effect, it represents a large segment of the market coming from an alternative tourism modality, making it easier to connect two realities and taking trips for mainly altruistic reasons, but also motivations that translate into better job opportunities and experiences, booming mainly among tourists from developed countries that are heading towards developing countries with great emphasis on the African continent. In this context, on April 16, 2016 on the north coast of the province of Manabi in Ecuador, the epicenter of an earthquake of 7.9 degrees on the scale of Ritcher caused human and material losses mostly in the provinces of Manabí and Esmeraldas. In the northwestern region of South America several plates converge: Caribbean, South American, Coco, Pacific, Nazca. According to official data from to the Secretariat of Risk Management of Ecuador and National Secretariat of Planning and Development SENPLADES (2016), this quake caused the death of 661 people, around 30,000 people were lodged in shelters, more than 80,000 left the site and economic losses are estimated at more than 3,00o million dollars.

The living conditions of the local population, especially of Manabí and south of Esmeraldas, were seriously affected, considering that previously SENPLADES (2016) had declared as a prioritized district the compound by the Jama and Pedernales cantons for the high levels of poverty and the lack of basic services and public infrastructure. It should be noted that the provinces of Esmeraldas and Manabí have historically been isolated from the social and economic development of the country, which has kept the region in a state of chronic socioeconomic depression that was terribly increasing with the earthquake. In this sense, activities such as trade, agriculture, livestock, fishing, small industry and tourism were affected. Thus, tourism was affected in coastal communities such as Pedernales, Caráquez Bay, Manta and Canoa, among others. Non-residents arrived at the destination to contribute with humanitarian support and reconstruction.

Since the 9os, the destination Manabí where the current research work was carried out, became a benchmark for exotic sun and beach tourism in Ecuador that attracts national and foreign visitors currently. After the telluric event, it was observed the involvement of different type and origin of organizations and specially people who without being tourists saturated the few rooms available for lodging and became part of the new urban landscape configured by huge spaces of tents and camps.

Disaster relief organizations, organizations sponsored by international organizations, organizations sponsored by national and foreign private companies, as well as local organizations of residents and natives, came to the city of Manabí to collaborate in various activities and maintain an economic activity on the site. The main aim of this empirical research is to analyze the motivations of a group of volunteer tourists and their satisfaction, establish findings on this subject and contribute to the state of the art. 


\section{THEORETICAL FRAMEWORK}

What really motivates a person to give their time and energy for causes that benefit other people through volunteering are diverse and intriguing. However, knowledge and understanding of this topic is of great interest to authors and administrators in charge of the selection process and recruitment (Esmond \& Dunlop, 2004).

There is no doubt that a new trend of travel is emerging and is linked to abandon mass tourism with its $3 \mathrm{~S}$ (sea, sand, sun) and focus on a different kind of tourism, alternative tourism (Gezici, 2006). Volunteer tourism is one of the types of tourism with the highest growth rates (Wearing \& McGehen, 2013) with around 1.6 million volunteers spending close to 2 billion dollars annually during the last decade (Wilkinson et al., 2014). This segment of volunteer tourists is characterized by the fact that its participants tend to be mainly young people under 35, with a high level of education and female (Hallmann \& Zehrer, 2016; Grimm \& Needham, 2012; Jackson \& Adarlo, 2014).

From a conceptual point of view, volunteer tourism is defined as an activity carried out by tourists during their holidays in an organized manner, seeking to achieve objectives such as: reduce poverty, help a particular group, investigate aspects of the environment or community that allow their conservation (Wearing, 2001). Likewise, authors like Sherraden et al. (2008) reflect on this activity as a contribution to society that exceeds the geo-political limits of the countries. It is also defined as a relationship of exchange where volunteers offer time, skills and energy in exchange for experiences (Hallmann \& Zehrer, 2016). Certain controversy arises on the part of Mostafahanezhad (2013) who comments that it is a neoliberal practice theme that seeks the justification of North American countries, individuals and organizations in the development of South American countries. In this perspective, since the 1970s, studies on volunteering and its motivation gained strength, going back to the 1980 s where conjectures and assumptions were asked whether motivations belonged to altruistic purposes or personal fulfillment. Authors such as Morrow-Howel \& Mui (1989) found that adults are encouraged to carry out this type of activities mainly for a humanitarian sense and secondly for personal fulfillment, which encouraged the scientific community to the emergence of two models: the one-dimensional and the multifactorial, but in spite of that the volunteers apparently are not aware of their main motivations (Cnaan \& Goldberg-Glen, 1991).

Later in 2004, one of the largest studies (2,444 participants) in formal research on motivations and volunteering conducted by Esmond and Dunlop (2004) was carried out in Australia, which involves the development of the volunteer motivation inventory. Based on that study, it was found that people do not carry out help activities because of their busy lives and the fact that organizations need to ensure that their time will be rewarded in improving the lives of others. In addition to these, three important aspects could be identified related to the meaning of volunteering: values, reciprocity and recognition (Esmond \& Dunlop, 2004). Then, the study carried out by Akintola (2010) in Africa provides more information, in this case about a group of volunteers destined to give attention to disease where it was found that their main motivation really had altruistic purposes such as concern for others and community. However, authors such as Barron and Rihova (2011) have identified that a large percentage of people volunteered for the purpose of improving their resume and having more opportunities in their careers. Likewise, in a study carried out in China by Chen and Chen (2011) after surveying volunteers, they identified that their main motivations were to experience authenticity, and interaction with local people and culture, which correspond to a more selfish or personal sense than altruistic one. Additionally, Wright (2013), after analyzing the perceptions, recognizes that there is still doubt on the part of the participant and guest 
about whether the true purpose of volunteering is altruism or personal purposes. Currently, Polus and Bidder (2016) agree that obtaining new experiences is more important than altruism when volunteering. On the other hand, Fuentes-Moraleda et al. (2016) conclude that interaction with different cultures and personal enrichment are the main reasons for moving towards solidarity activities, unlike the professional development that in this study was one of the least valued attributes. An additional study carried out among medical students who volunteered their services as medical volunteers identified that their main motivations revolved around the opportunities and the context of the trip as such, leaving aside the simple fact of giving their time to help the others (Rovers et al., 2016). In contrast to the motivations few studies have been carried out to analyze the impact of volunteer tourism in the community or on the experience of the participant (Hallmann \& Zehrer, 2016). For Han et al. (2019) the motivations of voluntary tourism contributed significantly to the creation of positive images, to the induction of satisfactory experiences and to the trust in a volunteer tourism organization. In this framework, the question arises of what are the motivational factors for voluntary tourism and what is the degree of satisfaction during the stay in a destination.

\section{STUDY AREA}

To the west of Ecuador is situated the province of Manabí where Canoa is located, which is a small urban area of almost 200 years old. Currently it belongs to the territorial jurisdiction of the San Vicente canton.

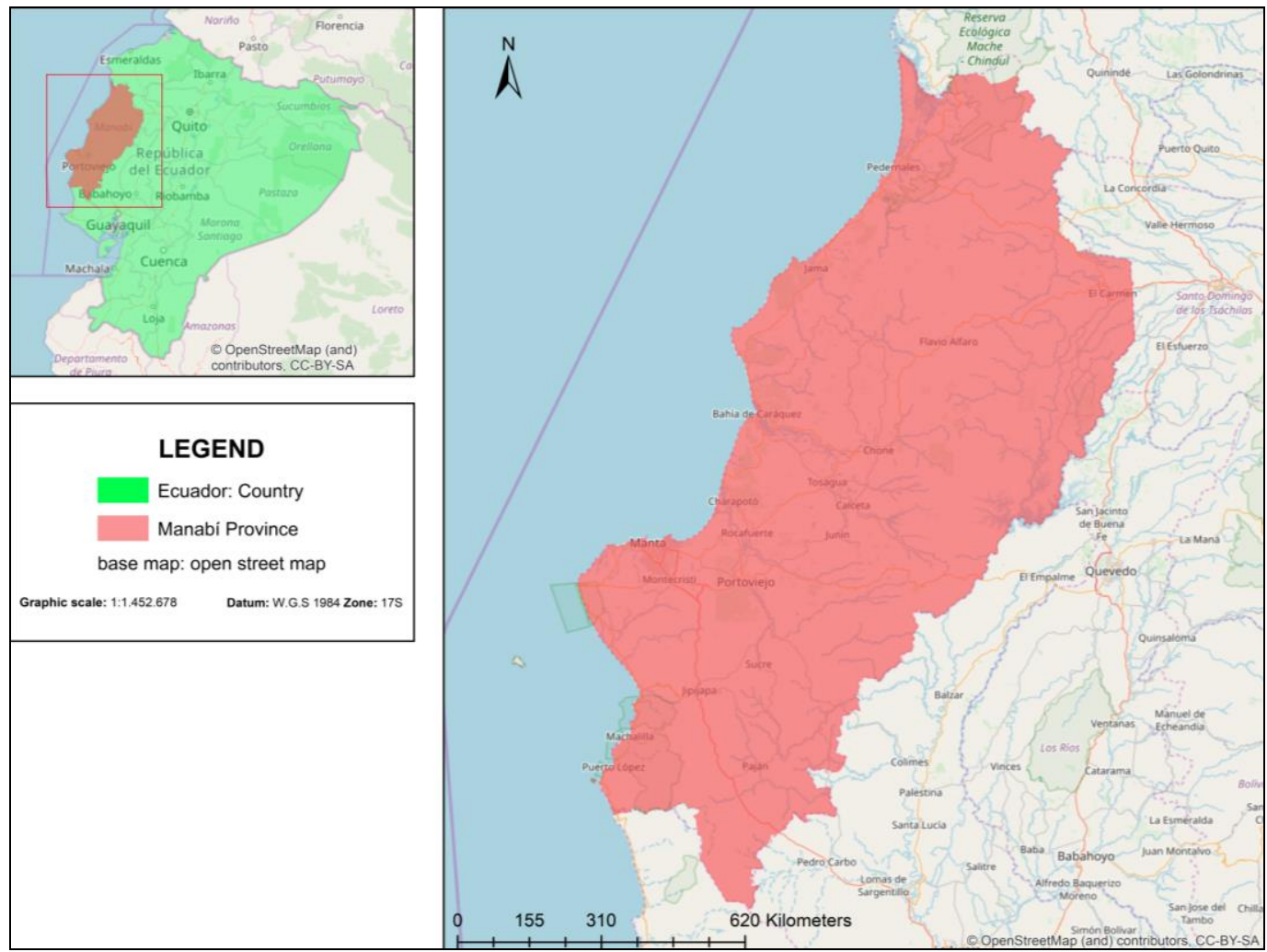

Figure 1. Geographical location of the province of Manabí (Ecuador) 
Geographically, it is on the northern edge of a wide beach with more than $5 \mathrm{~km}$ long, this beach is between the mouth of the Briceño river and a double mouth of the Canoa and Muchacho rivers where approximately 5,000 inhabitants live. Towards the north of the town, a rocky cliff formation begins that penetrates several kilometers in the Pacific Ocean in northwest direction, having like culminating point the Past Cape that constitutes a referent of navigation, referential limit of the Caráquez Bay and of the encounter of the currents of Humboltd and the Child The majority of the population is concentrated in Canoa where they coexist with a population of non-native residents dedicated to tourism and a floating population and constant flows of tourists. In the rural area the Montubia culture and a minority Afro descendant are evident in its population. (Figure 1).

\section{METHODOLOGY}

The present empirical study was based on a field study, for which a questionnaire was used based on different previous studies (Esmond \& Dunlop, 2004; Fuentes-Moraleda et al., 2016) where there are validated questionnaires on the subject of the volunteer tourism.

Table 1. Motivations of volunteer tourists

\begin{tabular}{|c|c|}
\hline Factors & Volunteer Motivations \\
\hline \multirow{3}{*}{$\begin{array}{l}\text { Career } \\
\text { Development }\end{array}$} & I volunteer because volunteering gives me an opportunity to build my work skills. \\
\hline & $\begin{array}{l}\text { I volunteer because I feel that I make important work connections through } \\
\text { volunteering. }\end{array}$ \\
\hline & $\begin{array}{l}\text { I volunteer because I feel that volunteering will help me to find out about } \\
\text { employment opportunities. }\end{array}$ \\
\hline \multirow{3}{*}{ Recognition } & Being appreciated by my volunteer agency is important to me. \\
\hline & Being respected by staff and volunteers at the agency is not important to me. \\
\hline & I feel that it is important to receive recognition for my volunteering work. \\
\hline \multirow{3}{*}{$\begin{array}{l}\text { Social } \\
\text { Interaction }\end{array}$} & I volunteer because I look forward to the social events that volunteering provides me. \\
\hline & I volunteer because I feel that volunteering is a way to build one's social networks. \\
\hline & I volunteer because volunteering provides a way for me to make new friends. \\
\hline Reciprocity & I volunteer because I believe that what goes around comes around. \\
\hline \multirow{3}{*}{ Empathy } & I like to help people, because I have been in difficult positions myself. \\
\hline & $\begin{array}{l}\text { Volunteering gives me a chance to try to ensure people do not have to go through } \\
\text { what I went through. }\end{array}$ \\
\hline & I often relate my volunteering experience to my own personal life. \\
\hline \multirow{3}{*}{ Self-Esteem } & I volunteer because volunteering makes me feel like a good person. \\
\hline & I volunteer because volunteering makes me feel useful. \\
\hline & I volunteer because volunteering keeps me busy. \\
\hline \multirow{2}{*}{ Social } & I volunteer because people I'm close to volunteer. \\
\hline & I volunteer because people I know share an interest in community service. \\
\hline \multirow{3}{*}{ Values } & I volunteer because I am concerned about those less fortunate than myself. \\
\hline & I volunteer because I am genuinely concerned about the particular group I am serving. \\
\hline & I volunteer because I feel it is important to help others. \\
\hline \multirow{3}{*}{$\begin{array}{l}\text { Under- } \\
\text { standing }\end{array}$} & I volunteer because volunteering allows me to gain a new perspective on things. \\
\hline & I volunteer because volunteering lets me learn through direct hands-on experience. \\
\hline & I volunteer because I can learn how to deal with a variety of people. \\
\hline \multirow{3}{*}{ Protective } & $\begin{array}{l}\text { I volunteer because doing volunteer work relieves me of some of the guilt for } \\
\text { being more fortunate than others. }\end{array}$ \\
\hline & I volunteer because volunteering is a good escape from my own troubles. \\
\hline & I volunteer because no matter how bad I am feeling, volunteering helps me forget about it. \\
\hline
\end{tabular}


The methodology provided by Esmond and Dunlop (2004) was used to adapt an appropriate survey for the destination and then the factorial analysis was applied as a data reduction technique, useful to explain the correlations between the variables observed in terms of a lower number of non-observed variables called factors (Table 1) The survey consisted of 14 questions, technically organized in three sections. The first section, the sociodemographic information of the tourists was required.

The second section focused on the volunteer motivations and in the third section the survey dealt with the visit satisfaction. Thus, closed-ended, multiple-choice questions were used with a 5-point Likert scale to assess opinions of respondents.

The field work was carried out during the months of July to September 2016 in the Province of Manabí in Ecuador (Localities: Canoa, Chone and Pedernales). The condition that the respondents had to meet were: That they were doing volunteer work, that they are not residents of the province of Manabí and that they are over 18 years of age. The personnel in charge of carrying out the surveys were students of ESPAM University Tourism Faculty. The questionnaire was filled in independently and the team of pollsters was very attentive to answer any questions from the respondents. In order to find errors and improve the survey, a pilot test was conducted with 20 surveys during a day to validate the questionnaire. A mixture of question techniques was used to try to obtain the most approximate results. 170 questionnaires were applied, of which 154 questionnaires were valid with a margin of error of $+/-8 \%$, a confidence level of $95 \%$ and a variance of $50 \%$. In the current research an infinite population as a sample was used because there was no official study to determine the number of volunteers who arrived in the province of Manabí (Ecuador). A representation of our sample design is presented in Table 2. SPSS Statistics software version 22 for analytical purposes was used in the current study.

Table 2. Sample design

\begin{tabular}{|l|l|}
\hline \multicolumn{1}{|c|}{ Population } & \multicolumn{1}{c|}{ Volunteers } \\
\hline Geographical area & Province of Manabí (Ecuador). Localities: Canoa, Chone, Pedernales. \\
\hline Data collection date & July-September 2016 \\
\hline Type of sampling & Simple random sampling \\
\hline Confidence level & $95 \%$ \\
\hline Margin of error & $+/-8 \%$ \\
\hline Valid questionnaires & 154 \\
\hline
\end{tabular}

\section{RESULTS AND DISCUSSION}

For a better understanding, the results of this study have been divided into four parts: Profile of the respondent, characteristics of the trip, motivations, and degree of satisfaction.

\section{Socio-demographic characteristics of volunteer tourist}

According to the responses in the survey, the sample was composed of foreign volunteers (53\%) and Ecuadorian volunteers (47\%). Regarding the gender, the $50 \%$ of volunteers were men and the remaining 50\% were women. Furthermore, the most representative group was formed between 20 to 29 years with $51.9 \%$, and between 30 to 39 years with $31.2 \%$. In relation to marital status of the respondents, the most representative groups were single (81.8\%) and married (9.1\%). The majority of respondents had university studies (68.2\%) (Table 3). Regarding the type of academic studies, $24.10 \%$ were related to engineering, followed by Management with $12.8 \%$ and tourism with $12.8 \%$ and then followed by Social Sciences with a $9.8 \%$.

\section{Tourist experience and characteristics of the volunteer trip}

In the current study $51.9 \%$ made a trip on their own, while $48.1 \%$ made a trip with the assistance of an NGO. The majority group, 29.2\% had participated more than 3 times 
in volunteer activities, followed by $27.7 \%$ who had never been volunteering. The vast majority, 51.3\%, spent more than a week in Manabí. Regarding the volunteer activities carried out in the destination during their stay, the majority of volunteers (43.10\%) devoted themselves to "civil constructions", followed by "teaching workshops" (11.8\%) and "pet care" (11.1\%). Among the types of tourism that the volunteers had experienced during their stay, community-based tourism $(56,205)$ and sun and beach tourism (47.70\%) were the most in demand, which shows the potential of this destination to have these types of tourism highly appreciated by volunteers. The question was of multiple answer and, therefore, the sum of the result is superior to $100 \%$.

Table 3. Socio-demographic characteristics of volunteer tourist

\begin{tabular}{|c|c|c|c|}
\hline Demographics & Categories & $\mathbf{n}$ & Percentage \\
\hline \multirow{2}{*}{$\begin{array}{l}\text { Origin } \\
\mathrm{N}=154\end{array}$} & National & 72 & 47.0 \\
\hline & Foreign & 82 & 53.0 \\
\hline \multirow{5}{*}{$\begin{array}{l}\text { Age group } \\
\mathrm{N}=154\end{array}$} & Under 20 & 9 & 5.8 \\
\hline & $20-29$ & 80 & 51.9 \\
\hline & $30-39$ & 48 & 31.2 \\
\hline & $40-49$ & 13 & 8.4 \\
\hline & $50-59$ & 4 & 2.6 \\
\hline \multirow{2}{*}{$\begin{array}{l}\text { Gender } \\
N=154\end{array}$} & Male & 77 & 50.0 \\
\hline & Female & 77 & 50.0 \\
\hline \multirow{5}{*}{$\begin{array}{l}\text { Marital Status } \\
\mathrm{N}=154\end{array}$} & Single & 126 & 81.8 \\
\hline & Common Law Marriage & 8 & 5.2 \\
\hline & Widowed & 2 & 1.3 \\
\hline & Married & 14 & 9.1 \\
\hline & Divorced & 4 & 2.6 \\
\hline \multirow{4}{*}{$\begin{array}{l}\text { Education level } \\
N=154\end{array}$} & Primary education & 4 & 2.6 \\
\hline & Secondary education & 13 & 8.4 \\
\hline & University education & 105 & 68.2 \\
\hline & Postgraduate & 32 & 20.8 \\
\hline
\end{tabular}

Table 4. Type of tourism practised during the trip

\begin{tabular}{|l|c|c|}
\hline \multicolumn{1}{|c|}{ Type of tourism } & Percentage & Ranking \\
\hline Community-based tourism & 56.2 & 1 \\
\hline Sun and beach & 47.7 & 2 \\
\hline Nature tourism & 39.9 & 3 \\
\hline Cultural tourism & 37.9 & 4 \\
\hline Experience-based tourism & 24.2 & 5 \\
\hline Adventure tourism & 21.6 & 6 \\
\hline
\end{tabular}

\section{Motivations of volunteer tourists}

One of the main objectives of this study is to know the motivations of volunteer tourists. For this, a Likert scale of 5 points was designed ( 1 being unimportant and 5 being very important). The Cronbach's Alpha coefficient is 0.890 , which indicates a commendable internal consistency among the elements of the scale.

\section{Factor analysis}

A factor analysis was carried out and it allowed to extract seven dimensions of motivation in the volunteer tourists. The analysis of main components has been used as a technique to reduce data. The Varimax rotation method was used, in order to obtain a 
clearer interpretation of the factors, so that each of them had only very high or low factor loads. The factors that had higher values than 1.00 were selected. Seven factors are part of the solution and represent $68.5 \%$ of the total variance. The results are shown in Table 5 .

Table 5. Rotated component matrix

\begin{tabular}{|c|c|c|c|c|c|c|c|}
\hline \multirow{2}{*}{ Factors } & \multicolumn{7}{|c|}{ Component } \\
\hline & $\mathbf{1}$ & 2 & 3 & 4 & 5 & 6 & 7 \\
\hline \multicolumn{8}{|l|}{ FACTOR 1: Social and professional development } \\
\hline $\begin{array}{l}\text { I volunteer because I feel that I make important work } \\
\text { connections through volunteering. }\end{array}$ & 0.879 & & & & & & \\
\hline $\begin{array}{l}\text { I volunteer because I feel that volunteering will help } \\
\text { me to find out about employment opportunities. }\end{array}$ & 0.827 & & & & & & \\
\hline $\begin{array}{l}\text { I volunteer because volunteering gives me an } \\
\text { opportunity to build my work skills. }\end{array}$ & 0.736 & & & & & & \\
\hline $\begin{array}{l}\text { I volunteer because I feel that volunteering is a way } \\
\text { to build one's social networks. }\end{array}$ & 0.509 & & & & & & \\
\hline $\begin{array}{l}\text { I volunteer because volunteering provides a way for } \\
\text { me to make new friends. }\end{array}$ & 0.504 & & & & & & \\
\hline $\begin{array}{l}\text { I volunteer because I look forward to the social } \\
\text { events that volunteering affords me. }\end{array}$ & 0.427 & & & & & & \\
\hline \multicolumn{8}{|l|}{ FACTOR 2: Values and Self- Esteem } \\
\hline I volunteer because I feel it is important to help others. & & 0.805 & & & & & \\
\hline $\begin{array}{l}\text { I volunteer because I am concerned about those less } \\
\text { fortunate than myself. }\end{array}$ & & 0.802 & & & & & \\
\hline $\begin{array}{l}\text { I volunteer because I am genuinely concerned about } \\
\text { the particular group I am serving. }\end{array}$ & & 0.741 & & & & & \\
\hline I volunteer because volunteering makes me feel useful. & & 0.483 & & & & & \\
\hline $\begin{array}{l}\text { I volunteer because volunteering makes me feel like a } \\
\text { good person. }\end{array}$ & & 0.438 & & & & & \\
\hline \multicolumn{8}{|l|}{ FACTOR 3: Empathy } \\
\hline $\begin{array}{l}\text { Volunteering gives me a chance to try to ensure } \\
\text { people do not have to go through what I went through. }\end{array}$ & & & 0.87 & & & & \\
\hline $\begin{array}{l}\text { I often relate my volunteering experience to my own } \\
\text { personal life. }\end{array}$ & & & 0.831 & & & & \\
\hline $\begin{array}{l}\text { I like to help people, because I have been in difficult } \\
\text { positions myself. }\end{array}$ & & & 0.756 & & & & \\
\hline $\begin{array}{l}\text { I volunteer because I believe that what goes around } \\
\text { comes around. }\end{array}$ & & & 0.453 & & & & \\
\hline \multicolumn{8}{|l|}{ FACTOR 4: Protective } \\
\hline $\begin{array}{l}\text { I volunteer because volunteering is a good escape } \\
\text { from my own troubles. }\end{array}$ & & & & 0.858 & & & \\
\hline $\begin{array}{l}\text { I volunteer because no matter how bad I am feeling, } \\
\text { volunteering helps me forget about it. }\end{array}$ & & & & 0.785 & & & \\
\hline $\begin{array}{l}\text { I volunteer because doing volunteer work relieves me of } \\
\text { some of the guilt for being more fortunate than others. }\end{array}$ & & & & 0.749 & & & \\
\hline I volunteer because volunteering keeps me busy. & & & & 0.494 & & & \\
\hline \multicolumn{8}{|l|}{ FACTOR 5: Understanding } \\
\hline $\begin{array}{l}\text { I volunteer because volunteering allows me to gain a } \\
\text { new perspective on things. }\end{array}$ & & & & & 0.746 & & \\
\hline
\end{tabular}




\begin{tabular}{|c|c|c|c|c|c|c|c|}
\hline $\begin{array}{l}\text { I volunteer because I can learn how to deal with a } \\
\text { variety of people. }\end{array}$ & & & & & \multicolumn{2}{|l|}{0.733} & \\
\hline $\begin{array}{l}\text { I volunteer because volunteering lets me learn } \\
\text { through direct hands-on experience. }\end{array}$ & & & & & 0.704 & & \\
\hline \multicolumn{8}{|l|}{ FACTOR 6: Social } \\
\hline $\begin{array}{l}\text { I volunteer because people I know share an interest } \\
\text { in community service. }\end{array}$ & & & & & & 0.861 & \\
\hline I volunteer because people I'm close to volunteer. & & & & & & 0.798 & \\
\hline \multicolumn{8}{|l|}{ FACTOR 7: Recognition } \\
\hline $\begin{array}{l}\text { Being appreciated by my volunteer agency is } \\
\text { important to me. }\end{array}$ & & & & & & & 0.61 \\
\hline $\begin{array}{l}\text { I feel that it is important to receive recognition for } \\
\text { my volunteering work. }\end{array}$ & & & & & & & 0.61 \\
\hline Eigenvalues & $7 \cdot 398$ & 3.05 & 2.467 & 1.752 & 1.36 & 1.3 & 1.14 \\
\hline \% explained variance & 27.402 & 11.3 & 9.136 & 6.49 & 5.04 & 4.9 & 4.21 \\
\hline$\%$ accumulated variance & \multicolumn{7}{|c|}{68.486} \\
\hline KMO & \multicolumn{7}{|c|}{0.794} \\
\hline Bartlett test of sphericity & \multicolumn{7}{|c|}{ Chi-square $=2040.056$. sig $<0,001$} \\
\hline
\end{tabular}

According to the results of Table 5, the KMO index was greater than 0.75 and the Barlett sphericity test is therefore significant that the model is adequate. The first factor was called "Professional and social development" and is the factor with the greatest explanatory capacity (27.4\%) of the total variance. This factor was associated with the motivations related to the opportunity to make connections and find opportunities to employment, building work skills and social relationships, making new friends and waiting for social events, similar findings were found (Barron \& Rihova, 2011; Chen \& Chen, 2011; Polus \& Bidder, 2016; Rovers et al., 2016). The second factor was called "Values and self-esteem" and explained $11.3 \%$ of the total variance. This factor was related to the motivations for helping others, for concern for the less fortunate, because volunteering makes respondents feel useful and like a good person. In the study by Esmond \& Dunlop, (2004) the "Values" factor was found as first. The third factor was called "Empathy" and explained $9.14 \%$ of the total variance. This factor was related to the motivations for trying to ensure that people do not have to go through what I went through, to relate my experience as a volunteer to my own personal life, because I have been in difficult positions too, because I believe that what goes around comes around.

The fourth factor was called "Protective" and explains $6.5 \%$ of the total variance. This factor was related to the motivations because, volunteering is a good escape from my own problems, because no matter how bad I feel, volunteering helps me to forget, because doing volunteer work relieves me from the guilt of being more fortunate than others, because volunteering keeps me busy. The fifth factor was called "Understanding" and explained 5.04\% of the total variance. This factor was related to the motivations because it allows me to get a new perspective on things, because I can learn to deal with a variety of people, because it allows me to learn through direct hands-on experience.

The sixth factor was called "Social" and represented for $4.9 \%$ of the total variance. This factor was related to the motivations because the people I know share an interest in community service and because the people close to me are volunteers. The seventh factor was called "Recognition" and represented for $4.2 \%$ of the total variance. This factor was 
related to the motivations for feeling appreciated by my volunteer agency, it is important for me and because I feel it is important to receive recognition for my volunteer work.

\section{Degree of satisfaction and loyalty of the tourist with the volunteer trips}

The overall satisfaction rating was high with an average of 4.32 out of a total of 5 , which shows that the volunteer tourist was satisfied during his stay in this destination. Results similar to (Fuentes, 2016). Thus, 94.1\% of respondents would repeat a trip for volunteer reasons, while $5.9 \%$ said they would not do it again. In addition, $97.40 \%$ would recommend to other people to carry out this type of trips with volunteer motivations.

As for whether their expectations were met on the trip, $94.1 \%$ of respondents answered yes, while $5.9 \%$ answered no. It was also asked if they would continue making these volunteer trips for which $93.5 \%$ answered yes, while $6.5 \%$ answered no.

Table 6. Expectation of the trip and degree of satisfaction

\begin{tabular}{|l|c|c|}
\hline \multicolumn{1}{|c|}{ Variable } & n & Percentage \\
\hline Very satisfied & 87 & 56.3 \\
\hline Satisfied & 48 & 31.3 \\
\hline Neither Satisfied nor Dissatisfied & 15 & 9.7 \\
\hline Unsatisfied & 4 & 2.8 \\
\hline Very unsatisfied & o & 0.0 \\
\hline
\end{tabular}

The relation that exists between the volunteers who fulfilled their expectation on the trip and the degree of satisfaction in their stay is shown in table 6. The results of Table 6 , show that $56.30 \%$ of volunteers, were very satisfied in this destination, so there was a high percentage of volunteers who got what they expected on this trip.

\section{CONCLUSIONS}

Among the conclusions it is possible to emphasize that the volunteer tourism represents an activity organized so that a specific group of tourists realize during their vacations in the pursuit of objectives such as: to reduce the poverty, to help a group in particular, to investigate aspects of the environment or community that allows its conservation (Wearing, 2001). Since the 1970s, this activity has gained strength as a reason for research, have been discussing whether it is altruism or a selfish sense that encourages tourists to do this activity. The latest research highlights the role of egoenhancement or personal sense as the main motivation for opting for this type of tourism (Chen \& Chen, 2011; Wright, 2013; Polus \& Bidder, 2016; Rovers et al., 2016).

Regarding the motivational dimensions, the findings show that the factors found in this destination using factorial analysis as a statistical technique, are seven: Professional and social development, values and self-esteem, empathy, protective, understanding, social, and recognition. Likewise, the findings show that the main factor in volunteer arrival is "Professional and social development" and is the factor with the greatest explanatory capacity (27.4\%) of the total variance (Barron \& Rihova, 2011; Chen \& Chen, 2011; Polus \& Bidder, 2016; Rovers et al., 2016).

The second factor that volunteers come to this destination is "Values and selfesteem" that explains (11.3\%) of the total variance. Likewise, Esmond and Dunlop (2004) in their research found that the "Value" factor was the main factor. These findings contribute to the theoretical implications, that the volunteer tourist mainly travels for "professional and social development", this factor is associated to the motivations related to the opportunity to make connections and find employment opportunities, for building job skills and social relationships, for making new friends 
and waiting for social events. Regarding the voluntary activities carried out in the destination, the majority of volunteers were engaged in "civil constructions", followed by "teaching workshops" and "pet care". The types of tourism that volunteers mainly carry out during their stay are: "community tourism" and "sun and beach tourism", which shows the potential of this type of tourism in this destination.

The general satisfaction assessment is high with an average of 4.32 out of a total of 5 , which shows the potential of this destination for volunteer tourism (Fuentes, 2016). The vast majority of respondents would repeat and recommend a trip for voluntary reasons, which suggests a loyalty of the volunteer tourist to the destination where he has collaborated, showing that the perception of the value of visiting a destination or participating in a specific type of travel strongly influences the future intention of travelers to return to the same destination or to participate again in a similar travel experience (Petrick, 2004). The $56.30 \%$ of volunteers were very satisfied in this destination, which denotes a relation between satisfaction and volunteering.

As practical implications, the study shows results that will help Manabi province (Ecuador) as a destination to continue with volunteer tourism as a development strategy for the reconstruction of this territory that is an area affected by the earthquake of 2016. Finally, it was found that the main limitation of the present study is its temporality. As a future line of research, it is suggested to apply the methodology recommended in Table 4, applying the seven factors obtained in the factor analysis in the same destination with the volunteers who keep coming to contrast the results and contribute to the state of art on this subject.

\section{REFERENCES}

Akintola, O. (2010). What motivates people to volunteer? The case of volunteer AIDS caregivers in faith-based organizations in KwaZulu-Natal, South Africa. Health policy and planning, 26(1), 53-62. https://doi.org/10.1093/heapol/czq019.

Barron, P., \& Rihova, I. (2011). Motivation to volunteer: a case study of the Edinburgh International Magic Festival. International Journal of Event and Festival Management, 2(3), 202-217. https: //doi.org/10.1108/17582951111170281.

Chen, L. J., \& Chen, J. S. (2011). The motivations and expectations of international volunteer tourists: A case study of "Chinese Village Traditions". Tourism Management, 32(2), 435-442. https:// doi.org/10.1016/j.tourman.2010.01.009.

Cnaan, R. A., \& Goldberg-Glen, R. S. (1991). Measuring motivation to volunteer in human services. The journal of applied behavioral science, 27(3), 269-284. https://doi.org/10.1177/0021886391273003.

Esmond, J., Dunlop, P. (2004). Developing the volunteer motivation inventory to assess the underlying motivational drives of volunteers in Western Australia.

Fuentes-Moraleda, L., Muñoz-Mazón, A., \& Rodríguez-Izquierdo, S. (2016). Responsible tourism as an instrument for local development: a case study to analyze the main motivations for tourists. Cuadernos de turismo, 227-242. http://dx.doi.org/10.6018/turismo.37.256221.

Gezici, F. (2006). Components of sustainability: Two cases from Turkey. Annals of Tourism Research, 33(2), 442-455. https://doi.org/10.1016/j.annals.2005.11.002.

Grimm, K. E., \& Needham, M. D. (2012). Moving beyond the "I" in motivation: Attributes and perceptions of conservation volunteer tourists. Journal of Travel Research, 51(4), 488-501. https:// doi.org/10.1177/0047287511418367.

Hallmann, K., \& Zehrer, A. (2016). How do perceived benefits and costs predict volunteers' satisfaction? VOLUNTAS: international journal of voluntary and nonprofit organizations, 27(2), 746767. https://doi.org/10.1007/s11266-015-9579-x.

Han, H., Meng, B., Chua, B. L., Ryu, H. B., \& Kim, W. (2019). International volunteer tourism and youth travelers-an emerging tourism trend. Journal of Travel \& Tourism Marketing, 36(5), 549-562. https://doi.org/10.1080/10548408.2019.1590293. 
Jackson, L., \& Adarlo, G. (2016). Bridging cultures through unpaid labor: US volunteer teachers' experiences in China's Yunnan Province. VOLUNTAS: International Journal of Voluntary and Nonprofit Organizations, 27(5), 2330-2352. https://doi.org/10.1007/s11266-014-9519-1.

Khetagurova, V. S., Kryukova, E. M., Maloletko, A. N., Kaurova, O. V., Mosalev, A. I., Mukhomorova, I. V., \& Egorova, E. N. (2018, December). Volunteer Tourism as a Variety of Responsible Tourism. In IOP Conference Series: Earth and Environmental Science (Vol. 204, No. 1, p. 012015). IOP Publishing. https://iopscience.iop.org/journal/1755-1315.

Morrow-Howell, N., \& Mui, A. C. (1989). Elderly volunteers: Reasons for initiating and terminating service. Journal of Gerontological Social Work, 13(3-4), 21-34. http://dx.doi.org/10.1300/Jo83V13No3_03.

Mostafanezhad, M. (2013). The politics of aesthetics in volunteer tourism. Annals of Tourism Research, 43, 150169. https://doi.org/10.1016/j.annals.2013.05.002.

Petrick, J. F. (2004). The roles of quality, value, and satisfaction in predicting cruise passengers' behavioral intentions. Journal of travel research, 42(4), 397-407. https://doi.org/10.1177\%2F0047287504263037.

Polus, R. C., \& Bidder, C. (2016). Volunteer Tourists' Motivation and Satisfaction: A Case of Batu Puteh Village Kinabatangan Borneo. Procedia-Social and Behavioral Sciences, 224, 308-316. https:// doi.org/10.1016/j.sbspro.2016.05.490.

Rovers, J., Japs, K., Truong, E., \& Shah, Y. (2016). Motivations, barriers and ethical understandings of healthcare student volunteers on a medical service trip: a mixed methods study. BMC medical education, 16(1), 94. https://doi.org/10.1186/s12909-016-0618-0.

Secretariat of Risk Management of Ecuador (2016). Report. Quito-Ecuador.

National Secretariat of Planning SENPLADES (2016). Report. Quito-Ecuador.

Sherraden, M. S., Lough, B., \& McBride, A. M. (2008). Effects of international volunteering and service: Individual and institutional predictors. Voluntas: International Journal of Voluntary and Nonprofit Organizations, 19(4), 395. https://doi.org/10.1007/s11266-008-9072-x.

Wearing, S. (2001). Volunteer tourism: Experiences that make a difference. New York: Cabi.

Rattan, J. K. (2015). Is certification the answer to creating a more sustainable volunteer tourism sector? Worldwide Hospitality and Tourism Themes, 7(2), 107-126. https://doi.org/ 10.1108/WHATT-12-2014-0047.

Wearing, S., \& McGehee, N. G. (2013). Volunteer tourism: A review. Tourism Management, 38, 120-130. https://doi.org/10.1016/j.tourman.2013.03.002.

Wilkinson, B., McCool, J. P., \& Bois, G. (2014). Voluntourism: An analysis of the online marketing of a fastgrowing industry. International journal of communication and health,2(4), $10-15$. http://communicationandhealth.ro/upload/number4/WILKINSON-MCCOOL-BOIS.pdf.

Wright, H. (2013). Volunteer tourism and its (mis) perceptions: A comparative analysis of tourist/host perceptions. Tourism and Hospitality Research, 13(4), 239-250. https:// doi.org/10.1177/1467358414527984.

Submitted:

26.03.2019
Revised:

17.07.2019
Accepted and published online 13.08.2019 